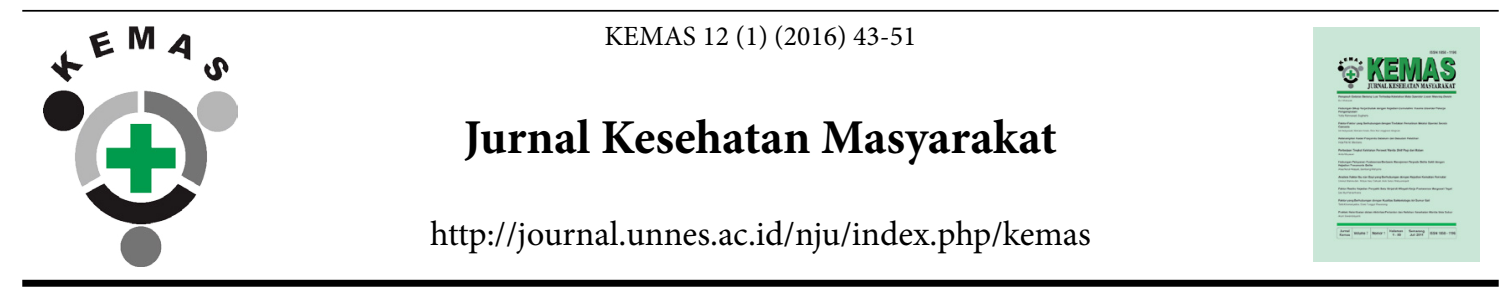

\title{
INORGANIC WASTE MANAGEMENT IN DECREASING MAYA INDEX AND ENTOMOLOGY INDEX OF MOSQUITO LARVAE
}

\author{
Lilik Zuhriyah $^{1 \bowtie}$, Tri Baskoro Tunggul Satoto ${ }^{2}$, Hari Kusnanto ${ }^{3}$ \\ ${ }^{1}$ Laboratorium of Public Health and Preventive Medicine, Medical School of Brawijaya University \\ ${ }^{2}$ Parasitology division, Medical Faculty, University of Gadjah Mada \\ ${ }^{3}$ Public Health Sciences division, Medical Faculty, University of Gadjah Mada
}

\begin{tabular}{l} 
Article Info \\
\hline Article History: \\
Submited September 2015 \\
Accepted June 2016 \\
Published July 2016 \\
\hline Keywords: \\
Inorganic waste; Maya \\
Index; Mosquito \\
\hline DOI \\
http://dx.doi.org/10.15294/ \\
kemas.v12i1.3976
\end{tabular}

\begin{abstract}
Inorganic waste management through Malang Waste Bank (BSM) is expected to reduce the risk of Dengue Hemorrhagic Fever (DHF). However, the number of neighborhood groups (RT) which become BSM participant varies. The problem is whether or not this variation will result in different entomology of mosquito larvae indexes. The purpose of this study is to prove the role of inorganic waste management to the risk of DHF transmission. Longitudinal survey was conducted weekly for 4 months in 2013 in six villages with the highest dengue cases in the city of Malang. Villages were classified into 3 types of membership of Malang Waste Bank (BSM). The result shows that the number of controllable containers is more than disposable container. Kruskal Wallis test mentions that the House Index (HI), Breteau Index (BI), Container Index (CI), and Density Index (DI) of the three villages are significantly different $(p<0.05)$, while $M I$ is not different. MI is related to all of mosquito larvae entomological indexes except with HI. Therefore, it can be concluded that the level of cleanliness of an area (MI) can be an indicator of the high index of mosquito larvae entomological indexes.
\end{abstract}

\section{Introduction}

Dengue Hemorrhagic Fever (DHF) is still a health problem in Indonesia. The data from Ministry of Health in 2014 reveals that the dengue morbidity rate which had declined from 2010 to 2011 increased again from 20122013, becoming 41.25 per 100,000 populations (Pusat Data \& Informasi Kementrian Kesehatan RI, 2014). One of the provinces that experienced extraordinary event of Dengue fever in Indonesia in early 2015 was East Java. The increase in cases occurred in January, both in 2013 and 2014. In 2013, out of 14,936 cases in a year, there were 3264 cases occurred in January. In 2014, out of 8906 cases in a year, 973 cases occurred in January. The number potentially increases in 2015 because until midJanuary, there are 378 cases and eight of them died (Pemerintah Provinsi Jawa Timur, 2015).

The vector control of Aedes mosquito is important as a prevention effort because until now, there is no available vaccines and drugs for dengue (WHO, 2009). One way is to reduce the vector control containers as a potential breeding site of Aedes aegypti. WHO recommends environmental management methods to prevent or minimize mosquito breeding and human contacts. One way is by the disposal or recycling inorganic waste. The principle of reduce, reuse, recycle is feasible in this case (WHO, 2009).

To overcome the problem of inorganic waste in the city of Malang, Malang Waste Bank (BSM) was established in 2012. With this, the BSM people can borrow money and pay for electricity with the money from the sale of garbage deposited in BSM. However, membership does not include all households in Malang. Some participants who have joined are individuals, some houses from one RT (20s), 
and some houses in a single RW but nearly all RTs are in it (20s). Not all households are willing and interested to join BSM altahough it offers financial benefits from inorganic waste management.

The focus of the study is on whether or not the BSM participation will generate the indices of different density of mosquito larvae. This research needs to be done to find out if the coaching at one RT will be sufficient to give good results as compared to fostering all RT in the medium level neighborhood, as this will affect the available resources.

Reduction of containers as a potential mosquito breeding sites can be measured by an index, namely Maya Index (MI). This index is obtained by combining Breeding Risk Indicator (BRI) and Hygiene Risk Indicator (HRI) (Danis-Lozano et al., 2002). Maya Index decline is expected to reduce some of the index number of density of Aedes larvae which includes House Index (HI), Breteau Index (BI), Container Index (CI), and the combination of the three indexes, namely Density Index (DI) (Focks, 2003).

This research generally aims at proving the role of inorganic waste management for the dengue transmission risk. In particular, this study aims to determine whether MI and the other indices of mosquito larvae density differ in the three types of BSM participation, and which of the indices of the density of larvae of Aedes is mostly associated with MI.

By knowing the indices of Aedes mosquito larvae density which is associated with the level of cleanliness (MI) of an area, Aedes mosquito larvae density and the risk of transmission can be predicted. Furthermore, it is important to do preventive measures immediately.

\section{Method}

This observational study with a longitudinal survey design was conducted in six villages in Malang in late September 2013 until the beginning of February 2014. The survey on mosquito larvae was carried out once a week for 12 times in four months to get the data of mosquito larvae density numbers which included HI, BI, CI , DI, and MI. Six urban villages that were chosen had the highest number of dengue fever patients in January-June 2013 in Malang, namely Jatimulyo, Merjosari, Sumbersari, Sawojajar, Bandulan, and Purwantoro villages. From each village, one RW which had the highest number of dengue fever patients was selected. The six RWs were different by type of participation in BSM. The number of houses surveyed in each RW were about 50-100 homes. These six areas were grouped into 3 groups: group 1 (which did not join BSM), group 2 (which joined BSM only $1 \mathrm{RT}$ ), and group 3 (which all RT joined BSM).

Maya Index was measured by combining Breeding Risk Indicator (BRI) and Hygiene Risk Indicator (HRI). Both indicators were categorized into high, medium and low according to tertile distribution. To obtain the MI, the three categories of BRI and HRI were plotted in a $3 \times 3$ matrix so MI with a category of high, medium and low can be obtained. Maya Index with high category means the risk of mosquito breeding was high and vice versa. High Maya Index was gained from high BRI/ high HRI, high BRI/medium HRI, and medium BRI/high HRI. Maya Index (with medium category was obtained from low BRI /high HRI, medium BRI / medium HRI, High BRI high/low HRI. And, low Maya Index (with low category) was obtained from low BRI / low HRI, medium BRI / low HRI and low BRI / medium HRI. BRI was obtained from the amount of containers that could be controlled divided by the average number of containers that could be controlled containing Aedes larvae per house among the surveyed households in a community. HRI was obtained from the amount of containers to be disposed divided by the number of containers that could be disposed containing Aedes larvae per house among the surveyed households in a community.

Kruskal Wallis and Mann Whitney test were used to determine the difference of each index by type of participation BSM. Spearman correlation test was used to determine the relationship between MI and the respective indexes mosquito larvae density. Maya Index analyzed in this study was the combined percentage of houses that had MI with medium and high categories.

\section{Results and Discussion}

The overview of research location can be 
seen in Table 1 where the six areas are slightly varied in terms of the number of RT, the total population, and the number of houses.

The table shows that group three has the highest number of RT, total population and number of houses. However, the density number of occupancy per house are almost flat that is at around 4 people per house.

Observing from the characteristics of BSM membership from four urban villages, Bandulan and Sawojajar Villages are the longest villages which join the BSM, followed by Purwantoro and Sumbersari villages. But among the four areas, Purwantoro village has the highest number of participants, followed by Sawojajar, Bandulan, and Sumbersari. The number of RT in the RW which participated in BSM does not significantly affect the number of participants. Participants of the RT could be more numerous than those of several RT. It is because of each RT only a few homes that want to join BSM (Table 2).

Based on the information from local health workers, some information related to BSM is revealed. These types of savings in the BSM may vary from one area to another area, but most of them are individualistic. Public interest to have individual savings in BSM is quite reasonable because the volume of inorganic waste per household can be different from each other. Individual savings are considered fairer for citizens. Because of its individualistic nature, the use of savings is much more individualistic.

Local health workers also mention that not all people are willing to join BSM despite financial benefits when they join it. Some of the reasons people do not join BSM is because they feel pity about cleaning officers who will get fewer litter for their additional income from selling the inorganic trash of the residents. Another reason is the difficulty in finding a place or a community that is willing to be a place to gather inorganic waste.

The survey results for four months (12 periods) shows that in general, the ownership of Controllable Container (CC) is more than Disposable Container (DC) in all groups (Table 3). This is in contrast with Danis-Lozano study which finds that DC is more than CC (DanisLozano, 2002). In conditions where the CC is more, the prevention of dengue mosquito larvae conducted through the survey is very important. In contrary, in conditions where the DC is more, then inorganic waste management becomes indispensable. Ownership of tin cans, bottles, and other garbage that includes DC in group one is larger than the other two groups. This shows that in villages that do not join the BSM, waste management seems to get less attention.

It also seems that the types of container which are widely used by residents in these three groups is bucket. The next containers are waste water storage of refrigerator, dispenser, barrel and so on. Some houses have at least one bucket/shower and even four. However, the bathrooms which positively have mosquito larvae are mostly the main bathroom. This condition is the same as research DanisLozano and Purnama which finds that bucket is the container that is most widely owned by residents and is most prevalent to mosquito larvae (Danis-Lozano et al., 2002; Purnama et al., 2012).

Other types of containers which commonly contain mosquito larvae in this study are barrel, dispenser, refrigerator, waste

Table 1. Demographic Characteristics of Research Location

\begin{tabular}{|c|c|c|c|c|c|c|c|c|c|c|}
\hline \multirow[b]{2}{*}{ No } & \multirow[b]{2}{*}{ Variables } & \multicolumn{3}{|c|}{ Group 1} & \multicolumn{3}{|c|}{ Group 2} & \multicolumn{3}{|c|}{ Group 3} \\
\hline & & $\begin{array}{l}\text { Jati- } \\
\text { mulyo }\end{array}$ & Merjosari & Total & $\begin{array}{l}\text { Sawo- } \\
\text { jajar }\end{array}$ & $\begin{array}{c}\text { Sumber- } \\
\text { sari }\end{array}$ & Total & $\begin{array}{c}\text { Bandu- } \\
\text { lan }\end{array}$ & Purwanotro & Total \\
\hline 1 & Number of RT & 10 & 3 & 13 & 6 & 5 & 11 & 8 & 15 & 23 \\
\hline 2 & Number of people & 3365 & 951 & 4316 & 1466 & 1584 & 3050 & 1556 & 3173 & 4729 \\
\hline 3 & Number of houses & 838 & 208 & 1046 & 345 & 362 & 707 & 385 & 811 & 1196 \\
\hline 4 & $\begin{array}{l}\text { Density number } \\
\text { of occupancy per } \\
\text { house }\end{array}$ & 4.02 & 4.57 & 4.12 & 4.25 & 4.38 & 4.31 & 4.04 & 3.91 & 3.95 \\
\hline
\end{tabular}

Description: *average 
Table 2. Characteristics of Implementing BSM At Research Location

\begin{tabular}{|c|c|c|c|c|c|}
\hline \multirow[b]{2}{*}{ No } & \multirow[b]{2}{*}{ Aspects } & \multicolumn{2}{|l|}{ Group 2} & \multicolumn{2}{|l|}{ Group 3} \\
\hline & & Sawojajar & $\begin{array}{l}\text { Sumber- } \\
\text { sari }\end{array}$ & Bandulan & $\begin{array}{l}\text { Purwan- } \\
\text { toro }\end{array}$ \\
\hline 1 & Starting to join BSM & $\begin{array}{l}\text { Septe mber } \\
2012\end{array}$ & $\begin{array}{l}\text { October } \\
2013\end{array}$ & 2012 & Feb 2013 \\
\hline 2 & Saving characteristics & group & individual & individual & individual \\
\hline 3 & $\begin{array}{l}\text { Number of members per } \\
\text { September } 2013\end{array}$ & 38 houses & 20 houses & 30 houses & 41 houses \\
\hline 4 & RT participants & $1 \mathrm{RT}$ & $1 \mathrm{RT}$ & all RT & all RT \\
\hline
\end{tabular}

water rear, and so on. Such containers are not mentioned in the study in Mexico (Danis et al, 2002). A research from Purnama in Denpasar also gets slightly different results where the containers which are most commonly owned by residents and became mosquito larvae breeding sites, in addition to buckets and the bathtub, are well, dispensers and tirta containers (Purnama, 2012). The results of the study in Malang is also a bit different from the results of research in urban areas of India where old tires, glass and paper glass are types of waste that contain mosquito larvae in them. In the area of industry, types of waste that contain mosquito larvae in them are water pump and unused electric tool (Dutta et al, 2006). This shows the role of cultural practices as one of the risks the discovery of the mosquito larvae. Factors from socio-cultural characteristics of a region also need to be considered in dengue vector control.

These findings reinforce the need to focus on prevention among key containers which are containers which positively contain larvae (Fock et al., 2003). However, the fact that the presence of larvae in the barrel, dispensers, waste water reservoirs (rear), refrigerator (old model) and other containers cannot be overlooked. From experience survey, researchers note that the presence of larvae is found in the barrel, dispensers, waste water reservoirs (rear) refrigerator (older models) are not known by the homeowners. This is because in general, the focus of prevention by the public is only directed at the shower and the barrel only. Research from Hiscox et al mention that filthy garbage, watering cans, bottles, tree, drums, used tires, and ditches often contain Aedes larvae more than buckets
(Hiscox et al, 2013). This means that mosquito larvae observation should be performed in all containers that could potentially hold water.

An important finding from Table 3 is that the percentage of positive containers mosquito larvae, both CC and DC, are more common in one group where the group is not BSM participant. It seems that it is distributed almost evenly on most types of containers. Therefore, prevention efforts also need to focus on villages that have not joined the BSM or do not have other inorganic waste management methods. The use of key areas on the basis of the density of mosquito larvae numbers can be an alternative strategy in entomology surveillance (Fock et al., 2003; Lagrotta et al., 2008). This strategy is expected to result in a more intensive intervention.

The combination of CC and DC (MI) which indicates the level of cleanliness or the risk of mosquito breeding sites are described in Table 4.

Based on MI category in Table 4, most villages has low MI category, followed by the category of medium and high. The groups that do not join the BSM have a lower percentage of MI with low categories as compared to the group that joins BSM. The percentage of , medium and high categories of MI for groups that do not join the BSM are slightly higher than villages which join BSM. The villages that do not join the BSM are dirtier and more likely to have high number of vector density as compared to villages that join the BSM.

Solid waste management (inorganic) can be regarded as the most effective vector prevention method e because it can reduce the density of Aedes larvae (Chen et al., 1994; 
Table 3. The Average Number of Houses based on Container Type and Average Percentage Based on Positive Container with Mosquito Larvae

\begin{tabular}{|c|c|c|c|c|c|c|}
\hline \multirow[t]{2}{*}{ Container types } & \multicolumn{3}{|c|}{$\begin{array}{l}\text { Average }^{\star} \text { number of houses } \\
\text { based on container types }\end{array}$} & \multicolumn{3}{|c|}{$\begin{array}{c}\text { Average }{ }^{*} \text { Percentage of houses } \\
\text { based on container with } \\
\text { mosquito larvae positive }\end{array}$} \\
\hline & Group 1 & Group 2 & Group 3 & Group 1 & Group 2 & Group 3 \\
\hline \multicolumn{7}{|l|}{ Controllable } \\
\hline Container (CC) & 28,90 & 25,19 & 24,37 & 1,93 & 1,24 & 1,91 \\
\hline Bucket/ BM 1 & 56,00 & 74,75 & 63,00 & 9,42 & 5,57 & 6,83 \\
\hline Bucket / BM 2 & 35,94 & 38,17 & 36,22 & 3,17 & 2,40 & 2,84 \\
\hline Bucket / BM 3 & 26,00 & 17,56 & 21,22 & 1,50 & 0,79 & 1,44 \\
\hline Bucket / BM 4 & 23,25 & 15,11 & 16,56 & 0,84 & 0,92 & 0,50 \\
\hline Dispenser & 32,31 & 27,39 & 29,56 & 2,58 & 0,91 & 1,50 \\
\hline Refrigerator $^{* *}$ & 35,58 & 40,31 & 36,69 & 2,11 & 0,83 & 2,12 \\
\hline Water vase & 22,19 & 13,28 & 11,75 & 0,00 & 0,21 & 3,31 \\
\hline Water Flower Pot & 24,17 & 13,64 & 12,19 & 0,34 & 0,20 & 2,05 \\
\hline $\begin{array}{l}\text { Water flower pot } \\
\text { pedestal }\end{array}$ & 22,14 & 13,25 & 12,03 & 0,00 & 0,00 & 0,92 \\
\hline Fish pond & 21,75 & 14,36 & 14,44 & 1,15 & 0,97 & 1,35 \\
\hline Aquarium & 23,89 & 15,92 & 16,53 & 0,35 & 0,52 & 0,67 \\
\hline Large water bowl & 27,08 & 25,28 & 28,17 & 2,87 & 2,31 & 1,18 \\
\hline Drinking pots $* * *$ & 25,36 & 18,50 & 18,42 & 0,77 & 0,45 & 0,15 \\
\hline \multicolumn{7}{|l|}{ Disposable } \\
\hline Container (DC) & 18,64 & 10,39 & 11,09 & 0,72 & 0,21 & 0,46 \\
\hline Cans & 25,36 & 14,03 & 14,64 & 0,77 & 0,40 & 0,76 \\
\hline Bottle & 21,75 & 11,69 & 13,39 & 0,77 & 0,24 & 0,62 \\
\hline Other trash & 8,81 & 5,44 & 5,25 & 0,63 & 0,00 & 0,00 \\
\hline
\end{tabular}

Description: ${ }^{*}$ calculated from 12 surveys for 4 months; $\mathrm{BM}=$ bath; ${ }^{*}$ Temporary Waste Water Fridge rear; ${ }^{* *}$ the drinking spot for animal / bird

Table 4. Percentage of Home Based on Maya Index and Groups Category

\begin{tabular}{llllllllll}
\hline & \multicolumn{3}{l}{ Group 1 (\%) } & \multicolumn{3}{c}{ Group 2 (\%) } \\
\cline { 2 - 10 } $\begin{array}{l}\text { Category } \\
\text { MI* }\end{array}$ & $\begin{array}{l}\text { Jati- } \\
\text { mulyo }\end{array}$ & $\begin{array}{l}\text { Merjo- } \\
\text { sari }\end{array}$ & Average & $\begin{array}{l}\text { Sumber- } \\
\text { Sari }\end{array}$ & $\begin{array}{l}\text { Sawo- } \\
\text { jajar }\end{array}$ & Average & $\begin{array}{l}\text { Bandu- } \\
\text { lan }\end{array}$ & $\begin{array}{l}\text { Purwan- } \\
\text { toro }\end{array}$ & Average \\
\hline Low & 91,57 & 94,93 & 93,25 & 94,78 & 97,11 & 95,95 & 93,72 & 95,81 & 94,77 \\
Medium & 8,14 & 4,96 & 6,55 & 5,22 & 2,89 & 4,06 & 5,98 & 4,19 & 5,09 \\
High & 0,81 & 0,38 & 0,595 & 0,00 & 0,00 & 0 & 0,90 & 0,00 & 0,45 \\
\hline
\end{tabular}

Description: ${ }^{*}$ calculated from 12 surveys for 4 months

Abeyewickreme et al., 2012). In addition to often inadvertently becomes reservoirs of the research in Vietnam, inorganic waste rainwater so that it becomes a breeding site for management is one intervention that is mosquitoes. The inorganic waste management likely to be sustainable (Hanh et al., 2009). should be a priority in dengue vector control Solid waste that is found outside the house (Banerjee et al., 2013). 
Descriptively, MI average for group one is also higher than the other two groups. This indicates that the village which is not managing inorganic waste containers is riskier to get mosquito larvae in their containers than villages which manage inorganic. Nevertheless, the result of Kruskal Wallis test shows no significant ( $p>0.05)$ between the mean scores of MI in three groups although group one is different than group two (Table 5).

The indices that show the number density of mosquito larvae (BI, CI, and DI) also show that the group one has a higher rate than group two and group three except for HI. HI value of group one even shows a lower number than groups two and three. This suggests that the containers which are positive with mosquito larvae originating from the little number of houses that are found to be positive for the mosquito larvae. Differences of mean density of mosquito larvae index numbers for all three groups is also proved significant ( $\mathrm{p}$ $<0.005)$ although the groups do not differ in the two groups. The absence of BSM in this area may lead to low public awareness to manage waste properly. It also shows that the number

Table 5. Maya Index, Density Score of Mosquito Larvae and Incidence Rate

\begin{tabular}{|c|c|c|c|c|c|c|c|c|c|c|}
\hline \multirow[t]{2}{*}{ No } & \multirow[t]{2}{*}{ Variables } & \multicolumn{2}{|c|}{ Group 1} & \multicolumn{2}{|c|}{ Group 2} & \multicolumn{2}{|l|}{ Group 3} & \multirow[b]{2}{*}{$\begin{array}{c}p \\
\text { value }\end{array}$} & \multirow[b]{2}{*}{$\mathbf{r}$} & \multirow{2}{*}{$\underset{\text { value }^{2}}{p}$} \\
\hline & & $\begin{array}{l}\text { Jati- } \\
\text { mulyo }\end{array}$ & $\begin{array}{l}\text { Merjo- } \\
\text { sari }\end{array}$ & $\begin{array}{l}\text { Sawo- } \\
\text { jajar }\end{array}$ & $\begin{array}{l}\text { Sumber- } \\
\text { sari }\end{array}$ & $\begin{array}{l}\text { Bandu- } \\
\text { lan }\end{array}$ & $\begin{array}{l}\text { Purwan- } \\
\text { toro }\end{array}$ & & & \\
\hline \multirow[t]{4}{*}{$1^{*}$} & MI before & 2.70 & 4.00 & 1.40 & 1.90 & 4.90 & 4.90 & \multirow{2}{*}{-} & \multirow{2}{*}{-} & \multirow{2}{*}{ - } \\
\hline & MI after & 0 & 2.10 & 2.80 & 0.50 & 2.20 & 10.50 & & & \\
\hline & Mean MI & $6,19^{\mathrm{A}}$ & & $3,84^{\mathrm{B}}$ & & $5,23^{\mathrm{AB}}$ & & 075 & 1 & - \\
\hline & MI decline & 1,21 & & 1,83 & & $-1,92$ & & - & - & - \\
\hline \multirow[t]{4}{*}{2} & HI before & 16.41 & 19.75 & 23.00 & 6.53 & 20.72 & 21.52 & & & \\
\hline & HI after & 10.00 & 24.74 & 17.98 & 0.97 & 5.97 & 21.05 & & & \\
\hline & Mean HI & $13,74^{\mathrm{A}}$ & & $18,19^{\mathrm{B}}$ & & $19,00^{\mathrm{B}}$ & &, 004 & $-0,02$ & 0,907 \\
\hline & HI decline & $-4,10$ & & 7,29 & & $-9,85$ & & - & - & - \\
\hline \multirow[t]{4}{*}{3} & CI before & 5.31 & 6.61 & 10.49 & 2.24 & 6.89 & 6.28 & \multirow{2}{*}{-} & \multirow{2}{*}{-} & \multirow{2}{*}{ - } \\
\hline & CI after & 5.00 & 14.81 & 7,86 & 0,32 & 1,63 & 3,28 & & & \\
\hline & Mean CI & $5,56^{\mathrm{A}}$ & & $3,46^{\mathrm{B}}$ & & $3,37^{\mathrm{B}}$ & & ,003 & 0,53 & 0,001 \\
\hline & CI decline & $-7,18$ & & 2,94 & & 4,31 & & - & - & - \\
\hline \multirow[t]{4}{*}{4} & BI before & 20.96 & 26.81 & 25.17 & 8.71 & 23.99 & 25.58 & & \multirow[t]{2}{*}{-} & \multirow{2}{*}{ - } \\
\hline & BI after & 10.00 & 32.99 & 20.22 & 0.97 & 5.97 & 21.05 & & & \\
\hline & Mean BI & $17,76^{\mathrm{A}}$ & & $9,45^{\mathrm{B}}$ & & $10,87^{\mathrm{B}}$ & &, 002 & 0,61 & 0,000 \\
\hline & BI decline & $-5,15$ & & 7,54 & & 15,63 & & - & - & - \\
\hline \multirow[t]{4}{*}{5} & DI before & 3.67 & 3.67 & 4.00 & 1.67 & 3.67 & 3.67 & & \multirow[t]{2}{*}{ 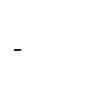 } & \multirow[b]{2}{*}{-} \\
\hline & DI after & 2.67 & 4.33 & 3.67 & 1.00 & 1.67 & 3.33 & & & \\
\hline & Mean DI & $3,58^{\mathrm{A}}$ & & $2,56^{\mathrm{B}}$ & & $2,72^{\mathrm{B}}$ & &, 002 & 0,615 & 0,000 \\
\hline & DI decline & $-0,33$ & & 1,00 & & 0,34 & & - & - & - \\
\hline \multirow[t]{3}{*}{6} & IR before ${ }^{* * 3}$ & 11.89 & 10.52 & 81.86 & 31.57 & 38.56 & 25.21 & - & \multirow{2}{*}{ - } & \multirow[b]{2}{*}{-} \\
\hline & IR after $* * * 3,4$ & 2.97 & 31.55 & 0 & 0 & 6,43 & 22.06 & & & \\
\hline & IR decline & 2,32 & & 55,74 & & 12,69 & & - & - & - \\
\hline
\end{tabular}

Description: before $=$ mean survey of period $1 \& 2$; after the survey period $=18 ;{ }^{1}=$ Result of Kruskal Wallis test of mean between groups (12 surveys), $\mathrm{n}=12$ per group; Mann Whitney Test Results Values in the same row followed by the same letter are not significantly different ( $p>0.05)$; ${ }^{2}=$ Spearman correlation test results of 12 surveys ( 4 months), $\mathrm{n}=36 ;^{3}=$ per 10,000 population; ${ }^{4}=$ per August 2014; ${ }^{\star}$ Percentage MI with category - high; ${ }^{\star *}$ Data from Health Center from January to June, 2013; ${ }^{* * *}$ Data from Health Center from March to August, 2014 
of mosquito larvae density (Breteau Index, Container Index and Density Index) is sensitive to the presence of containers mainly positive mosquito larvae.

In general, it appears that the three areas are included in the category of risk of dengue due to $\mathrm{DI}>1, \mathrm{HI}>5 \%$, and $\mathrm{BI}>5$ (Fock et al., 2003). In this study, CI is the only one that does not exceed the threshold of $10 \%$. Nonetheless, because the density index of other vectors have exceeded the threshold, then the vigilance against the spread of dengue remains to be done with preventive activities such as cleaning the containers in the house that are often found mosquito larvae, as well as cleaning up the environment around the home from rubbish that could potentially accommodate water.

The high percentage of houses with medium-high category of MI proves to be an indicator of high number of mosquito larvae density. Spearman's correlation test results show the relationship between MI with some of the index. Some mosquito larvae density numeric indices which show positive association with MI levels are DI, BI and CI. Sequentially the use of $\mathrm{BI}$ as an indicator of the density numbers of larvae in an area has quite high sensitivity and specificity at $81.8 \%$ and $73.3 \%$ (Sanchez et al, 2010). The use of BI as an index of mosquito larvae density estimators is better than $\mathrm{HI}$ and CI. This is because HI does not consider the number of positive containers with mosquito larvae, while the CI does not consider the number of containers per area, per home, or per person. Density Index itself is an index promoted by WHO (Fock, 2003). Alvira research also supports this finding. In his research, he has found that endemic villages have higher MI than non-endemic villages, as well as BI and CI which are obtained are difference. And HI does not show any difference between the two characteristic of villages (Alvira et al., 2009). The different result is shown by Sukowinarsih that finds no relationship between the presence of mosquito larvae in old containers with the incidence of dengue. However, these studies use smaller samples in case-control studies, whereas in this study the data which is obtained through longitudinal survey (Sukowinarsih et al, 2010).

Another important finding from Table
5 is that generally, the mosquito larvae density index (BI, CI, and DI) groups two and three (both of which are participants of BSM) have decreased (before deducting after) as compared to the group one who actually shows an increase. Only MI and HI are lacking to support these findings. However, the decline Incidence Rate of BSM participant groups (two or three) is more than the group of non-participants BSM.

Research from Arunachalam et al also mentions the decreasing number of vector density which is associated with ecohealth intervention methods involves waste management and clean-up activities therein (Arunachalam et al., 2012). Similarly, Alvira research says that endemic villages have greater MI than the village which is not endemic (Alvira et al., 2009).

This research is conducted in location where waste management services run normally, yet the trash is still found. This shows that people's behavior in disposing of waste still need to be improved. Officers of waste carrier will usually only transport the waste that has been prepared in the trash. Trash can become mosquito's breeding sites (Arunachalam et al., 2012).

Numbers of RTs which become BSM participants do not appear to affect the value of MI. This is because the number of RT participants does not show the large number of households participating in BSM. The participation of several houses in the BSM is apparently not able to attract the surrounding residents to join BSM as well. Perhaps, the value of $\mathrm{MI}$ is more in related to population and the number of houses, in which the more the number of houses and population, the greater the chances to have inorganic waste in the region. To be able to attract more people to join the BSM, it will require other innovations which are capable of maintaining harmony among fellow members of the community and between the community members and the cleaning officer in their respective areas. Moreover, the fact that good waste management can reduce the risk of outbreaks of dengue fever should be emphasized in Malang city community.

Waste management in general becomes one of the interventions in preventing dengue fever which involves the community (Khun, 
2008). The community can be involved in the separation of waste that is part of a strategy of Integrated Vector Management (IVM) in the prevention of dengue fever (Wai et al, 2012). Community involvement in the prevention of dengue is important because society occupy the place of residence on a daily basis. But unfortunately, the behavior of mosquito eradication is considerably still low. This is mainly because the lack of knowledge, attitude, availability of information, and the role of cadres and health officials are still less active. The high-workload of health worker wlead to the risk of decreasing the accuracy of the monitoring results Score Free Flick (Nuryanti, 2013).

\section{Conclusion}

Waste management is one potential method to reduce containers which are potential as mosquito breeding sites in dengue vector control. While the mosquito vector control itself is a dengue prevention method which is very important. However, routine monitoring of mosquito larvae once a week is still important because controllable container is more than disposable container.

The level of cleanliness and the number density of mosquito larvae in the village which join BSM in inorganic waste management are proven to be better than the villages that have not joined BSM yet. In addition, a decrease Incidence Rate (IR) of dengue in the villages which join BSM is proven higher than in villages that have not joined yet. Therefore, by knowing the level of cleanliness (MI) of a region, the number of dengue vector density (DI, BI and CI) can also be predicted because there is a relationship between these indices with MI.

\section{References}

Abeyewickreme, W., Wickremasinghe, A.R., Karunatilake, K. Sommerfeld, J., and Kroeger, A. 2012. Community Mobilization and Household Level Waste Management for Dengue Vector Control in Gampaha District of Sri Lanka; An Intervention Study. Pathogens and Global Health, 106 (8) :479487

Alvira, N., Satoto, T.B.T., and Murtiningsih, B, 2009. Differences of Risk Factor that Affect The Existence of The Larvae Dengue Vector (Aedes aegypti and Aedes albopictus)
Between The Endemic and Sporadic Villages in Banguntapan Sub Distric Bantul District. Medika Respati. Jurnal Ilmiah Kesehatan, IV (4) :69-87

Arunachalam, N., Tyagi, B.K., Samuel, M., Krishnamoorthi, R., Manavalan, R., Tewari, S.C., et al. 2012. Community-based Control of Aedes aegypti by Adoption of Eco-health Methods in Chennai City, India. Pathogens and Global Health, 106 (8): 488-496

Banerjee, S., Aditya, G., and Saha, G.K. 2013. Household Disposables as Breeding Habitats of Dengue Vectors: Linking Wastes and Public Health. Waste Management, 33 : 233239.

Chen Y.R., Hwang J.S., and Guo Y.J. 1994. Ecology and Control of Dengue Vector Mosquitoes in Taiwan. The Kaohsiung Journal of Medical Sciences : 10 Suppl:S78-87.

Danis-Lozano, R., Rodríguez, M.H., and Hernández-Avila, M. 2002. Gender-Related Family Head Schooling and Aedes aegypti Larval Breeding Risk in Southern Mexico. Salud Pública Méx; 44(3):237-242

Dutta, $P$ and Mahanta, J. 2006. Potential Vectors of Dengue and the Profile of Dengue in the North-Eastern Region of India: An Epidemiological Perspective. Dengue Bulletin, $30: 234-242$

Focks, D.A. 2003. A Review of Entomological Sampling Methods and Indicators for Dengue Vectors. Special Programme for Reseach and Training in Tropical Diseases. Geneva: World Health Organization.

Hanh, T.T.T., Hill, P.S., Kay, B.H. and Quy, T.M. 2009. Development of a Framework for Evaluating the Sustainability of Communitybased Dengue Control Projects. American Journal of Tropical Medicine and Hygiene, $80(2): 312-318$

Hiscox, A., Kaye, A., Vongphayloth, K., Banks, I., Piffer, M., Khammanithong, P., et al. 2013. Risk Factors for the Presence of Aedes aegypti and Aedes albopictus in Domestic WaterHolding Containers in Areas Impacted by the Nam Theun 2 Hydroelectric Project, Laos. American Journal of Tropical Medicine and Hygiene, 88(6): 1070-1078

Khun, S and Manderson, L. 2008. Community Participation and Social Engagement in the Prevention and Control of Dengue Fever in Rural Cambodia. Dengue Bulletin, 32: 145155

Lagrotta, M.T.F., Silva, W.C., and Souza-Santo, R. 2008. Identification of Key Areas for Aedes Aegypti Control Through Geoprocessing in 
Nova Iguaçu, Rio de Janeiro State, Brazil. Cad. Saúde Pública, Rio de Janeiro, 24(1):7080.

Nuryanti, E. 2013. Perilaku Pemberantasan Sarang Nyamuk di Masyarakat. Jurnal Kesehatan Masyarakat : 9 (1) 15-23

Pemerintah Propinsi Jawa Timur. 2015. Meski Angka Kasus Menurun, Wagub Tegaskan Jatim Masih Darurat DBD. http://www.jatimprov. go.id/site/meski-angka-kasus-menurunwagub-tegaskan-jatim-masih-darurat-dbd/ Diupload pada 25 Januari 2015. Diakses pada 24 Januari 2015.

Purnama, S..G. and Satoto, T.B.T. 2012. Maya Index dan Kepadatan Larva Aedes aegypti terhadap Infeksi Dengue. Makara Kesehatan, 16 (2): 57-64

Pusat Data dan Informasi Kementrian Kesehatan RI. 2014. Situasi Demam Berdarah Dengue di Indonesia. Infodatin. Kemenkes RI
Sanchez, L., Cortinas, J., Pelaez, O., Gutierrez, H., Concepcio'n, D., and Stuyft, PV. 2010. Breteau Index Threshold Levels Indicating Risk for Dengue Transmission in Areas With Low Aedes Infestation. Tropical Medicine and International Health, 15 (2):173-175

Sukowinarsih, T.E., and Cahyati, W.H. 2010. Hubungan Sanitasi Rumah Tangga dengan Angka Bebas Jentik Aedes aegypti. Jurnal Kesehatan Masyarakat 6 (1) :30-35

Wai, K.T., Htun, P.T., Oo, T., Myint, H., Lin, Z., Kroeger,A., Sommerfeld, J., and Petzold, M. 2012. Community-centred Eco-bio-social Approach to Control Dengue Vectors: an Intervention Study from Myanmar. Pathogens and Global Health, 106 (8): 461-468

WHO. 2009. Dengue. Guidelines for Diagnosis, Treatment, Prevention and Control. New Edition. Switzerland WHO/ HTM/ NTD/ DEN 